\title{
Growth and energetics in the ascidian Ciona intestinalis
}

\author{
Jens Kjerulf Petersen, Ole Schou, Peter Thor
}

National Environmental Research Institute, Frederiksborgvej 399, PO Box 358, DK-4000 Roskilde, Denmark

\begin{abstract}
Rates of growth, filtration and respiration of the ascidian Ciona intestinalis (L.) were measured in the laboratory in the presence of food (flagellate Rhodomonas sp.) concentrations ranging from 0 to 12000 cells $\mathrm{ml}^{-1}$ ( 0 to $500 \mu \mathrm{g} \mathrm{Cl}^{-1}$ ). Weight-specific growth rate (dry weight of body parts not including the tunic) increased sigmoidally with increasing algal cell concentration to $7.7 \% \mathrm{~d}^{-1}$ Maximum specific growth rate was related to age rather than size. A condition index $\left(\mathrm{CI}=\mathrm{DW} W_{\text {body }} / \mathrm{DW}\right.$ total) reflected level of growth. Specific filtration rate decreased logarithmically with increased algal cell concentration. Weight-specific respiration rate showed a relation to algal cell concentration similar to that shown by weight-specific growth rate. All rates were transformed into units of carbon, and a carbon budget was established for 2 size groups. Assimilation efficiency (AE) was approximately $50 \%$ but decreased at the highest carbon concentrations. The amount of carbon assimilated per body unit that was needed to maintain body (not including the tunic) or total (including the tunic) carbon was independent of initial size and amounted to 10 or $16 \mu \mathrm{gC} \mathrm{mg} \mathrm{C}^{-1} \mathrm{~d}^{-1}$, respectively. Gross growth efficiency (GGE) and net growth efficiency (NGE) varied with food concentration and approached a level of 0.23 or 0.78 , respectively, in terms of body carbon. In terms of total carbon, GGE was found to be 0.27 to 0.28 and NGE to be 0.79 . Costs of maintenance were greater in the largest ascidians, while costs of body growth were equal in the 2 size groups $(0.21$ to 0.23$)$
\end{abstract}

KEY WORDS: Ascidian - Growth - Respiration - Food concentration - Carbon budget

\section{INTRODUCTION}

The solitary epibenthic ascidian Ciona intestinalis (L.) f. typica has a worldwide distribution from subarctic to tropical regions (Dybern 1965) and can occur in very high densities (>5000 $\mathrm{m}^{-2}$; Millar 1971). In shallow waters in temperate regions, $C$. intestinalis is an annual with 2 distinct growth seasons: in summer/fall after settling and metamorphosis and in spring/early summer before spawning (Millar 1952, 1971, Dybern 1965). Sampling in various localities in northern Europe has shown that $C$. intestinalis can grow up to 10 to $20 \mathrm{~mm} \mathrm{mo}^{-1}$ (Dybern 1965), and Yamaguchi (1975) found that in situ growth in C. intestinalis hatched and settled in the laboratory was dependent on temperature and size. Finally, in a laboratory experiment, growth rates of $0.7 \%$ length $\mathrm{d}^{-1}$ were found when $C$. intestinalis was fed cultured algae (Robbins 1985). However, to our knowledge, no data are available on growth potential and actual growth at different food levels, and an energy or carbon budget has not yet been established for $C$. intestinalis nor any other ascidian. Such studies are available for suspension feeding bivalves (see Jørgensen 1990, Riisgård 1991) but there is a shortage of studies that relate growth, assimilation and metabolism of marine invertebrates.

In general, peak growth rates obtained in the laboratory on mussels fed a diet of pure cultured algae have been less than the maximum growth rates obtained in the field (Jørgensen 1990). It has recently been suggested that this may be due to the use of unnaturally high algal concentrations in the laboratory leading to suboptimal conditions with reduced filtration rates (Riisgård \& Randløv 1981, Riisgård 1991). In Ciona intestinalis, filtration rates have recently been found to decrease with increasing algal cell concentration (Petersen \& Riisgård 1992).

The purpose of the present study was to assess growth and growth potential in Ciona intestinalis, with emphasis on the effects of differences in algal cell 
concentrations within a range of naturally occurring concentrations. Further, a carbon budget was established based on measurements of ingestion, growth and respiration. To evaluate effects of size/age of the ascidians on growth, experiments were performed at 3 different times of the year: in August/September, when the ascidians are relatively newly settled, in December at the end of the growth season, and in March before spawning season.

\section{MATERIALS AND METHODS}

In Expt I growth was determined as a function of algal cell concentration from initial and final weight and length of the ascidians. Ciona intestinalis were collected in December 1992 at 2 to $3 \mathrm{~m}$ depth in Kertinge Nor on the east coast of Fyn, Denmark, and taken to Fjord Biological Laboratory, Kerteminde, where the growth experiment was performed. In Expts II and III C. intestinalis were collected in March and August 1993 at 3 to $4 \mathrm{~m}$ depth in Vellerup Vig (Isefjorden) in the northern part of Sjælland, Denmark, and taken to the National Environmental Research Institute. In addition to growth, ingestion and respiration were determined. Further, a subsample of ascidians was weighed in the middle of the experiment in order to determine weight increment as a function of time. A carbon budget was established from measurements of carbon content of food and test organisms. In Expt III intial and final length were determined.

In all experiments ascidians were, upon arrival at the laboratory, placed in holding tanks with running seawater of ambient salinity ( 18 to $20 \%$ ) and acclimated to the experimental temperature $\left(10^{\circ} \mathrm{C}\right)$ for 1 to $2 \mathrm{wk}$. Before an experiment, a number of ascidians with approximately equal body length in relaxed state were selected and divided into groups. One group of ascidians was used to estimate mean dry weight of body and tunic at Day 0 . The rest were placed in the experimental aquaria and fed different concentrations of algae for 13 to $16 \mathrm{~d}$. A subsample was taken after 7 to $8 \mathrm{~d}$ (Expts II \& III) to determine whether growth was linear or exponential. Body (not including the tunic) and total (body including the tunic) dry weight were determined after the ascidians had been separated into tunic and body, flushed with distilled water and dried at $90^{\circ} \mathrm{C}$ for $24 \mathrm{~h}$. For analysis of $\mathrm{C}$ and $\mathrm{N}$ content, bodies from Expt II were pooled from each treatment (algal concentration) while tunics were pooled from all treatments. In Expt III, bodies and tunics were separately pooled for each treatment and analyzed $(\mathrm{n}=3$ ) for $\mathrm{C}$ and $\mathrm{N}$ content on a Perkin-Elmer $240 \mathrm{C} \mathrm{CHN-analyzer.}$ Basic data on duration, number of individuals and initial (and final) weights and $C$ content in each experiment and treatment are given in Table 1 . Initial and

Table 1. Ciona intestinalis. Mean $( \pm \mathrm{SD})$ daily algal concentration, initial and final weights and $C: \mathrm{N}$ ratios of body parts (body: not including tunic; total: including tunic). $\mathrm{n}$ : indicates number of ascidians weighed. Experimental temperature was $10 \pm 0.5^{\circ} \mathrm{C}$

\begin{tabular}{|c|c|c|c|c|c|c|c|c|c|c|c|c|c|}
\hline $\begin{array}{c}\text { Algal } \\
\text { concentration } \\
\text { (cells } \mathrm{ml}^{-1} \text { ) }\end{array}$ & $\begin{array}{l}\text { Initial w } \\
\text { Body } \\
\text { (mg) }\end{array}$ & $\begin{array}{r}\text { eight }\left(W_{0}\right) \\
\text { Total } \\
(\mathrm{mg})\end{array}$ & $\mathrm{n}$ & $\begin{array}{l}\text { Final we } \\
\text { Body } \\
(m g)\end{array}$ & $\begin{array}{r}\text { eight }\left(W_{j}\right) \\
\text { Total } \\
(\mathrm{mg})\end{array}$ & $\mathrm{n}$ & $\begin{array}{l}\text { Duration } \\
\text { (d) }\end{array}$ & \multicolumn{3}{|c|}{$\begin{array}{l}\text { Initial C:N } \mathrm{N}^{\mathrm{a}} \\
\text { Body } \\
\% \mathrm{C} \% \mathrm{~N} C: \mathrm{N}\end{array}$} & \multicolumn{3}{|c|}{$\begin{array}{c}\text { Final C: } \mathrm{N}^{\mathrm{a}} \\
\text { Body } \\
\% \mathrm{C} \% \mathrm{C}: \mathrm{N}\end{array}$} \\
\hline \multicolumn{14}{|l|}{ Expt I } \\
\hline 0 & $10.9 \pm 2.7$ & $22.2 \pm 6.4$ & 15 & $9.8 \pm 2.5$ & $22.0 \pm 8.7$ & 20 & 13 & & & & & & \\
\hline $2949 \pm 919$ & - & - & - & $24.2 \pm 6.6$ & $40.1 \pm 10.5$ & 18 & 13 & & & & & & \\
\hline $5986 \pm 2301$ & $16.2 \pm 4.1$ & $34.5 \pm 7.6$ & 15 & $29.7 \pm 5.7$ & $49.8 \pm 11.0$ & 14 & 13 & & & & & & \\
\hline $11976 \pm 2610$ & - & - & - & $28.8 \pm 6.5$ & $48.4 \pm 11.5$ & 17 & 13 & & & & & & \\
\hline \multicolumn{14}{|l|}{ Expt II } \\
\hline 0 & $49.7 \pm 6.6$ & $120.2 \pm 12.1$ & 30 & $49.5 \pm 9.8$ & $135.2 \pm 10.1$ & 10 & 10 & 20.58 & 5.36 & 3.8 & 20.29 & 5.47 & 3.7 \\
\hline $947 \pm 204$ & $39.1 \pm 5.5$ & $100.3 \pm 10.2$ & 14 & $61.6 \pm 8.6$ & $121.9 \pm 18.6$ & 11 & 13 & - & - & - & 21.06 & 5.43 & 3.9 \\
\hline $1833 \pm 390$ & $45.1 \pm 6.1$ & $118.7 \pm 9.1$ & 13 & $82.9 \pm 10.8$ & $155.9 \pm 14.9$ & 11 & 15 & - & - & - & 23.16 & 5.78 & 4.0 \\
\hline $3078 \pm 729$ & $50.4 \pm 4.7$ & $127.5 \pm 9.8$ & 16 & $106.0 \pm 23.9$ & $192.3 \pm 36.8$ & 11 & 15 & - & - & - & 23.09 & 5.16 & 4.5 \\
\hline $5700 \pm 1138$ & $46.0 \pm 6.9$ & $107.2 \pm 12.9$ & 18 & $90.8 \pm 18.6$ & $160.7 \pm 19.5$ & 11 & 15 & - & - & - & 29.15 & 7.04 & 4.1 \\
\hline $7569 \pm 1962$ & $54.7 \pm 7.6$ & $132.3 \pm 10.9$ & 12 & $105.6 \pm 14.8$ & $193.0 \pm 19.8$ & 12 & 15 & - & - & - & 31.55 & 7.34 & 4.3 \\
\hline \multicolumn{14}{|l|}{ Expt III } \\
\hline 0 & $12.6 \pm 1.7$ & $24.1 \pm 3.6$ & 34 & $9.7 \pm 1.7$ & $22.2 \pm 2.7$ & 13 & 16 & 27.88 & 7.52 & 3.7 & 27.48 & 7.60 & 3.6 \\
\hline $474 \pm 135$ & - & - & - & $19.3 \pm 3.6$ & $34.7 \pm 4.6$ & 14 & 16 & - & - & - & 28.53 & 7.49 & 3.8 \\
\hline $842 \pm 178$ & - & - & - & $26.7 \pm 4.6$ & $44.7 \pm 6.7$ & 17 & 16 & & - & - & 28.60 & 7.56 & 3.8 \\
\hline $1884 \pm 265$ & - & - & - & $32.7 \pm 5.5$ & $53.1 \pm 10.0$ & 16 & 16 & - & - & - & 28.80 & 7.23 & 4.0 \\
\hline $3922 \pm 693$ & - & - & - & $41.3 \pm 8.3$ & $65.6=12.0$ & 18 & 16 & - & - & - & 28.92 & 7.36 & 3.9 \\
\hline $8226 \pm 1034$ & - & - & - & $43.8 \pm 7.5$ & $70.4 \pm 11.2$ & 15 & 16 & - & - & - & 30.20 & 7.58 & 4.0 \\
\hline
\end{tabular}


Table 2. Ciona intestinalis. Initial and final mean length $( \pm \mathrm{SD})$ and specific growth rate from Expts I and III

\begin{tabular}{|cccc|}
\hline $\begin{array}{c}\text { Algal } \\
\text { concentration } \\
\left.\text { (cells } \mathrm{ml}^{-1}\right)\end{array}$ & $\begin{array}{c}\text { initial length } \\
(\mathrm{mm})\end{array}$ & $\begin{array}{c}\text { Final length } \\
(\mathrm{mm})\end{array}$ & $\begin{array}{c}\text { Growth } \\
\left(\% \mathrm{~d}^{-1}\right)\end{array}$ \\
\hline $\begin{array}{c}\text { Expt I } \\
0\end{array}$ & $30.6 \pm 3.9$ & $29.8 \pm 3.3$ & -0.20 \\
$2949 \pm 919$ & - & $41.1 \pm 4.1$ & 2.27 \\
$5986 \pm 2301$ & $36.2 \pm 3.6$ & $41.4 \pm 3.2$ & 1.03 \\
$11976 \pm 2610$ & - & $40.3 \pm 3.9$ & 0.83 \\
Expt III & & & \\
0 & $35.2 \pm 3.1$ & $35.2 \pm 3.4$ & 0 \\
$474 \pm 135$ & - & $46.4 \pm 4.2$ & 1.73 \\
$842 \pm 178$ & - & $50.6 \pm 3.9$ & 2.27 \\
$1884 \pm 265$ & - & $51.8 \pm 4.5$ & 2.41 \\
$3922 \pm 693$ & - & $54.7 \pm 4.2$ & 2.76 \\
$8226 \pm 1034$ & - & $52.1 \pm 5.2$ & 2.45 \\
\hline
\end{tabular}

final length were measured on individual ascidians in relaxed state (Table 2).

During the experiment the ascidians were fed continuously with the cultured flagellate Rhodomonas sp. (equivalent spherical diameter, $\mathrm{ESD}=6 \mu \mathrm{m}$ ). Concentrations of algae were varied between aquaria $(0$ to 12000 cells $\mathrm{ml}^{-1}$ ) by regulating the dosing rates from, and the cell concentration in, the algal dosing flasks. Concentrations of algae in the experimental aquaria in all experiments, and in Expts II and III in the dosing flasks, were measured at least once every day as number of cells $\mathrm{ml}^{-1}$ with an Elzone 180 electronic particle counter or, at the lowest concentrations in Expt III, by visual counting under an inverted microscope. The cell concentrations in the experimental aquaria were corrected for non-algal particles by determining particle concentration in the water, which was sampled just before it entered the experimental aquaria. Temperature was measured daily in all experiments. The amount of particulate organic matter (POM) in water entering the experimental aquaria was measured every second day by filtering 10 to 201 on a Whatmann $\mathrm{GF} / \mathrm{C}$ filter, rinsing with distilled water and drying for $24 \mathrm{~h}$ at $90^{\circ} \mathrm{C}$. Algae $(\mathrm{n}=12)$ and $\mathrm{POM}(\mathrm{n}=4)$ samples from Expts II and III were analyzed for carbon and nitrogen on a Perkin-Elmer 240C CHN-analyzer and chlorophyll a content according to Jespersen \& Christoffersen (1987).

Experimental setup. Fig. 1 shows the setup used for growth experiments at different algal concentrations. Algal suspension from the dosing flasks was added to the experimental aquaria $(20 \times 39 \mathrm{~cm}, 15 \mathrm{l})$ by a peristaltic pump. A flow of sea water was passed through the experimental aquaria at a rate of approximately $100 \mathrm{ml} \mathrm{min}{ }^{-1}$. Before entering the experimental aquaria, the sea water passed through an aquarium containing Mytilus edulis in order to reduce the amount of POM. In Expt III water was filtered through a Sartorius Sartobran $0.45 \mu \mathrm{m}$ filter after passing through the aquarium containing $M$. edulis but before entering the experimental aquarium that had no agal cells added to it. By sampling at various depths and distances from the wall, we were able to test whether the aeration of the aquaria ensured a homogenous algal suspension. Each ascidian was fastened, by sewing or glueing, to a mesh raised from the bottom of the experimental aquarium.

Metabolic rate. Ascidians from growth experiments (II and III) were used for respiration measurements at the end of the experiments. Individual specimens were placed in $35 \mathrm{ml}$ glass chambers each equipped with a magnetic stirrer at the bottom. The chambers were closed with silicone stoppers fitted with stainless steel tubing and connected to the electrode with Tygon tubing. Respiration chambers as well as reservoirs and connecting tubing were placed in a thermobath kept at $10^{\circ} \mathrm{C}$. To ensure a steady respiration rate, the ascidians
Fig. 1. Experimental setup for growth experiments

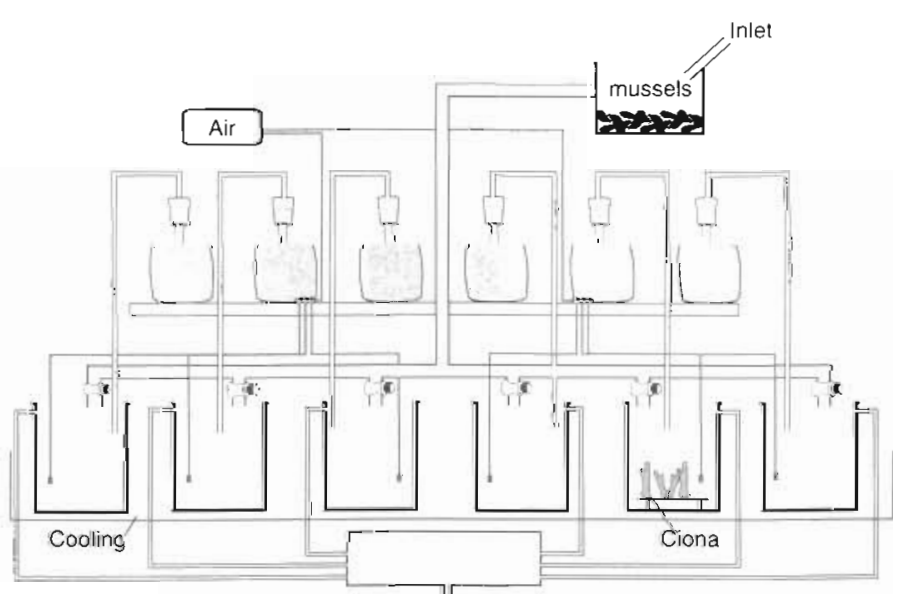

Front view of experimental setup

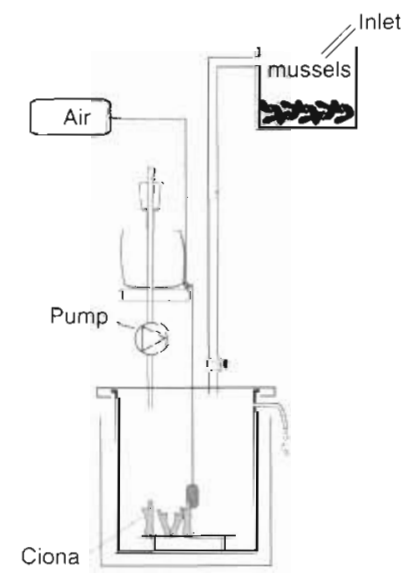

Side view 
were allowed $1 \mathrm{~h}$ of acclimation after both siphons were fully extended. Algae were added to the inflow reservoirs to obtain concentrations equal to those of the experimental aquaria. For each treatment 7 to 10 ascidians were measured. After respiration measurements, weight, length and carbon content of the test ascidians were measured in a manner similar to that in the growth experiments.

Respiration rates in Expt II were measured using a flow-through system as described by Møhlenberg \& Kiørboe (1981). Flow rate was $1.55 \mathrm{ml} \mathrm{min}^{-1}$ and respiration rate in each ascidian was measured twice during a period of at least $2 \mathrm{~h}$. In Expt III an intermittent-flow system as described by Steffensen (1.989) was used and 3 repeated measurements were made for each individual ascidian. In both experiments, chamber (blank) respiration was estimated by measuring $\mathrm{O}_{2}$ consumption of chambers containing no Ciona intestinalis. Respiration of each ascidian was calculated as a mean of 2 and 3 measurements in Expts II and III respectively, correcting for blank respiration.

Analyses and statistics. Growth: To test for significant changes in weight, initial and final dry weights (ln-transformed) were compared using a 1-way ANOVA followed by a Scheffe $F$-test. In Expts II and III weight was measured 3 times $(0,7$ to 8 and $16 \mathrm{~d}$ ), and weight increment as a function of time showed the best fit with an exponential relation; specific growth rate $(G)$ for all experiments was therefore calculated as $G=$ $\left[\ln \left(D W_{1}\right)-\ln \left(D W_{0}\right)\right] / t$, where $D W_{0}$ is the mean dry weight or carbon content at Day 0 and DW, is the individual dry weight or carbon content at Day $t$. Specific growth rates were compared as described above. A condition index (CI) was calculated for all treatments as body dry weight ( $\left.\mathrm{DW}_{\text {body }}\right)$ divided by total dry weight ( $\mathrm{DW}_{\text {total }}$ ).

Ingestion: Algal concentrations were compared between treatments using a Kruskal-Wallis test on mean daily concentrations since no transformations could make the data satisfy the demand for homoscedasticity. In Expts II and III the rate of ingestion $(I)$ of algae was calculated as $I_{\text {alg }}=C_{1} \times F_{1}-C_{0} \times F_{0}$. where $C_{1}$ and $C_{0}$ are mean cell concentration for each day during the experiment in the dosing flask and outflow, respectively, $F_{\mathrm{i}}$ is the dosing rate, and $F_{0}$ is the rate of outflow from the experimental aquarium. Since POM could not totally be eliminated by passing the water through an aquarium containing Mytilus edulis, ingestion of POM was estimated as $I_{\mathrm{POM}}=F_{0} \times E \times$ $C_{\text {POM }}$, where $E$ is the percentage of algal cells that are retained in the experimental aquaria $\left[\left(C_{1} \times F_{\mathrm{i}}-C_{0} \times\right.\right.$ $\left.\left.F_{0}\right) /\left(C_{\mathrm{i}} \times F_{\mathrm{i}}\right)\right]$ and $C_{\text {POM }}$ is the concentration of POM in water having passed through the $M$. edulis aquarium but before having entered the experimental aquaria. In aquaria with no added algal cells, I POM was calculated using $E$ from the treatment with the lowest addition of algal cells. Filtration rate defined as clearence of $100 \%$ efficiently retained particles was calculated as $I_{\text {aigae }} / C_{0}$. Average daily weight or carbon-specific ingestion and filtration rates were calculated as averages of daily specific rates using daily weight or carbon content. These were estimated using an exponential relation to interpolate between initial and final weights or carbon content. Total carbon concentration in the test aquaria was calculated as algal carbon + non-algal carbon. Non-algal carbon was estimated from data on $C_{\mathrm{i}}, F_{\mathrm{i}}, F_{\mathrm{o}}$ and $E$, assuming identical retainment of algal cells and non-algal POM in the different treatments.

Respiration: Differences in specific respiration rates between treatments were compared with a 1-way ANOVA followed by a Scheffe $F$-test. Specific respiration rates in $\mu \mathrm{O}_{2} \mathrm{~d}^{-1} \mathrm{mg}^{-1}$ were converted to $\mu \mathrm{g} \mathrm{C} \mathrm{d}^{-1}$ $\mu \mathrm{g} \mathrm{C}^{-1}$ according to Kiørboe et al. (1985), but adjusted to $10^{\circ} \mathrm{C}$ and $760 \mathrm{~mm} \mathrm{Hg}$.

\section{RESULTS}

There was a significant difference $(p<0.001)$ in algal cell concentration between treatments in all 3 experiments. No significant difference between visual and electronic counts could be detected. Since no difference in concentration of POM in seawater entering the experimental aquaria in Expts II and III could be detected, a mean POM concentration of $0.181 \mathrm{mg}$ DW $1^{-1}$ was used for all treatments in Expts II and III, except the 0 -algae treatment in Expt III, where the $0.45 \mu \mathrm{m}$ filter reduced the mean POM-concentration to $0.017 \mathrm{mg} \mathrm{DW}^{-1}$. There were significant $(\mathrm{p}<0.05)$ changes in weight (Table 1 ) in all treatments except in the 0-algae treatment in Expt II. Growth rate in terms of body dry weight increased sigmoidally with increasing food concentration (Fig. 2), approaching a plateau of $5 \% \mathrm{~d}^{-1}$ in the winter experiments (I and II) or $8 \% \mathrm{~d}^{-1}$ in the summer experiment (III). At algal concentrations below 3000 cells $\mathrm{ml}^{-1}$ there was a significant $(p<0.05)$ difference in specific growth rate between treatments in all experiments. At algal concentrations above 3000 cells $\mathrm{ml}^{-1}$ specific growth rates were significantly higher $(p<0.05)$ than at lower algal concentrations, but there were no significant differences between treatments. A significant positive relation $\left(\mathrm{r}^{2}=0.81\right)$ between growth and condition index (CI) was found (Fig. 3) with positive growth rates above $\mathrm{CI}=0.46$. Growth rates in terms of length are shown in Table 2 and increased sigmoidally with increasing algal concentration.

In Expts II and III, filtration rates could be calculated from data on concentrations in dosing flasks and outflow and are shown in Fig. 2 as a function of algal con- 

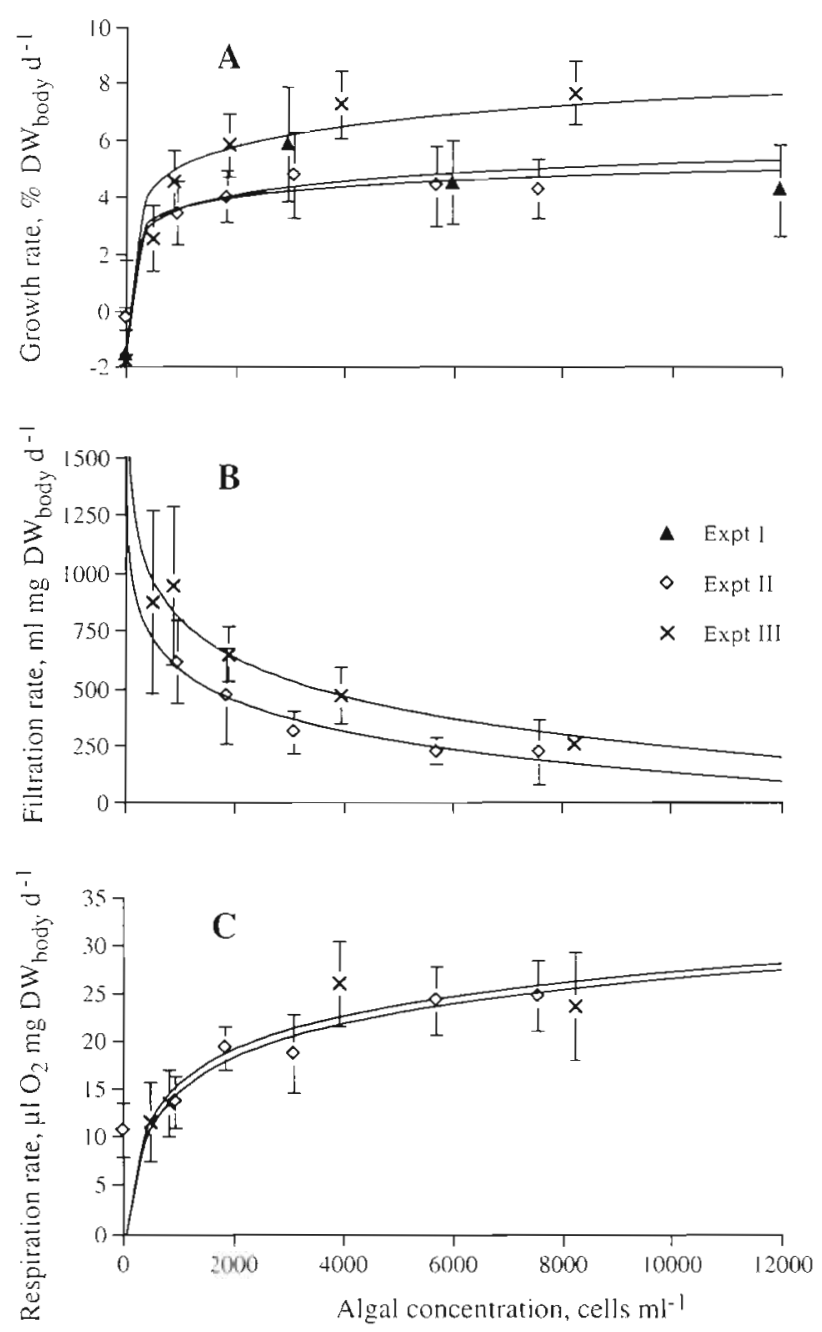

Fig. 2. Ciona intestinalis. Effect of variation in concentration of Rhodomonas sp. algal cells (A) on the following: (A) Specific growth rate of body parts $(G$, mean $\pm S D)$. For Expts I to III fitted curves are $G=-1.31+1.6 \log A\left(r^{2}=0.89\right), G=-0.17$ $+1.2 \log A\left(r^{2}=0.97\right)$, and $G=-2.23+2.4 \log A\left(r^{2}=0.93\right)$ respectively. (B) Weight-specific filtration rate $(F$, mean $\pm \mathrm{SD})$. For Expts II and III fitted curves are $F=1925-448 \log A\left(\mathrm{r}^{2}=\right.$ $0.94)$ and $F=2450-552 \log A\left(r^{2}=0.93\right)$ respectively. (C) Weight-specific respiration rate $(R$, mean $\pm \mathrm{SD})$. For Expts II and III fitted curves are $R=-21.3+11.9 \log A\left(\mathrm{r}^{2}=0.93\right)$ and $R=-19.6+11.7 \log A\left(\mathrm{r}^{2}=0.87\right)$ respectively

centration. Specific filtration rate was dependent on food level, decreasing logarithmically with increasing algal cell concentration above approximately 1000 cells $\mathrm{ml}^{-1}$.

The weight-specific respiration rate showed a relation to algal cell concentration similar to that shown by specific growth rate (Fig, 2), In Expt II there was a significant $(p<0.05)$ difference in respiration rate between 0 , 1000,2000 and 3000 cells $\mathrm{ml}^{-1}$ and 6000 and 8000 cells $\mathrm{ml}^{-1}$. The maxi-

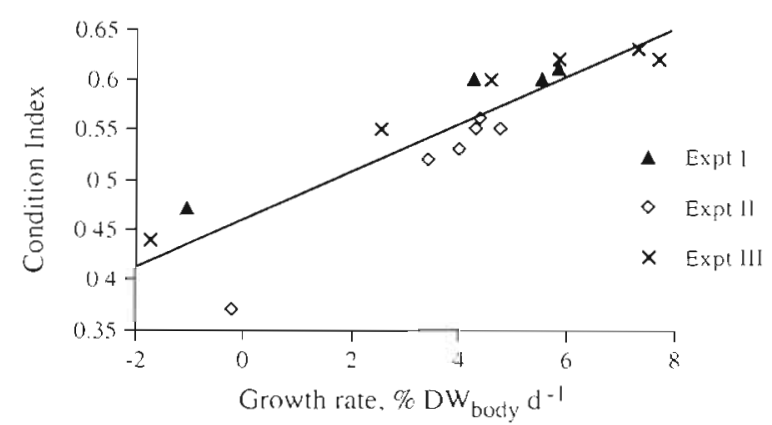

Fig. 3. Ciona intestinalis. Condition Index (CI, mean $\pm \mathrm{SD})$ as a function of specific growth rate of body parts $(G)$. Common line is fitted by $\mathrm{Cl}=0.46+0.024 G\left(\mathrm{r}^{2}=0.81\right)$

mum specific respiration rate was $24.8 \mu \mathrm{l} \mathrm{O} \mathrm{O}^{-1} \mathrm{mg}$ $\mathrm{DW}_{\text {body }}{ }^{-1}$. There was a significant $(\mathrm{p}<0.05)$ difference in respiration rates between treatments in Expt III, except for the 2 lowest and the 2 highest algal cell concentrations. Maximum specific respiration rate was $26.0 \mathrm{H} \mathrm{O}_{2} \mathrm{~d}^{-1} \mathrm{mg} \mathrm{DW}_{\text {body }}{ }^{-1}$. Due to technical problems, respiration rates at 0 and 2000 cells $\mathrm{ml}^{-1}$ in Expt III could not be obtained. For calculations of the energy budget in Expt III, respiration rate in starving ascidians was obtained from ascidians collected in March which had starved at the site of collection during the winter and were kept unfed in the laboratory for at least $1 \mathrm{wk}$ before respiration was measured. The respiration rate for starving ascidians was $6.65 \pm 1.88 \mu \mathrm{l} \mathrm{O} \mathrm{O}^{-1} \mathrm{mg}$ $D W_{\text {body }}{ }^{-1}(n=9)$, which was significantly less $(p<0.05)$ than that of growing Ciona intestinalis. Ascidians used for respiration experiments did not differ significantly in growth rate from ascidians from the same treatment that had not been used for respiration experiments.

For the computation of an energy budget, carbon content of algal cells and POM were measured (Table 3) and specific rates of ingestion, growth and respiration were converted to units of carbon (Fig. 4, Table 4). Carbon content of Ciona intestinalis was different between treatments and that affected the carbon-specific rates of both growth and respiration. This was especially pronounced in Expt II (winter), where the greatest increase in carbon content with increasing growth was found and growth rates in terms of carbon were almost identical in magnitude to those found in

Table 3. Mean $( \pm S D)$ content of carbon, nitrogen and chlorophyll $a$ in algae (pg cell ${ }^{-1}$ ) and POM (\%) from Expts II and III. ND: concentrations in $20 \mathrm{lof}$ filtered sample were below levels of detection

\begin{tabular}{|lcccc|}
\hline Species & $\mathrm{C}$ & $\mathrm{N}$ & $\mathrm{C} / \mathrm{N}$ & Chlorophyll $a$ \\
\hline Rhodomonas sp. & $42.12 \pm 1.42$ & $10.71 \pm 1.05$ & $4.0 \pm 0.36$ & $1.31 \pm 0.32$ \\
POM & $26.25 \pm 1.16$ & $5.53 \pm 0.63$ & $4.77 \pm 0.36$ & ND \\
\hline
\end{tabular}




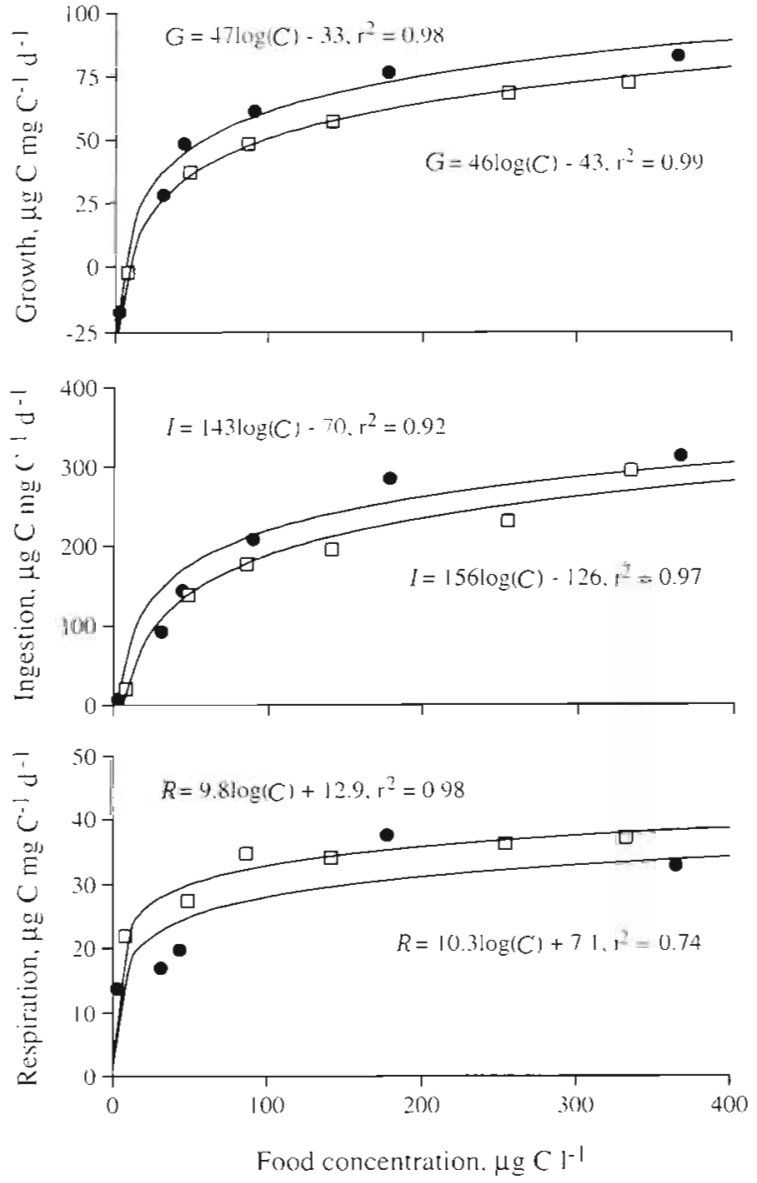

Fig. 4. Ciona intestmalis. Mean carbon specific rates of growth $(G)$, ingestion $\left(I=I_{\text {algae }}+I_{\text {POM }}\right)$ and respiration $(R)$ of body parts as a function of food concentration $(C=$ algae + POM), (口): Expt II, (•): Expt III. Fitted lines and equations are shown in the figure
Expt III (summer). Since body parts of $C$. intestinalis and algae had similar $\mathrm{C}: \mathrm{N}$ ratios of about 4 , conversion to nitrogen units can be obtained by dividing the axes by 4 .

Calculated assimilation efficiencies (AE) and net and gross growth efficiencies (NGE and GGE) are also shown in Table 4. AE in Expt II were almost constant at 47 to $50 \%$, except at the highest food concentration, but decreased with increasing food concentration in Expt III. GGE were highest at the intermediate food concentrations, which is also reflected in the logarithmic relation between specific growth and ingestion rate (Fig. 5). AE and GGE were always highest when calculated using total weight (body including tunic) as a basis.

The amounts of carbon ingested or assimilated per body unit needed to maintain body weight were identical in the 2 experiments (Fig. 5). As can be seen from Fig. 5, there is a linear relation between specific growth and assimilation rate, and NGE therefore increases with increasing assimilation (Table 4). Specific respiration rate at a given specific ingestion or assimilation rate was found in general to be highest in Expt II (Fig. 5).

Costs of maintenance, that is respiration at zero growth, were greater in the largest specimens (Fig. 6), while costs of growth $(\mathrm{d} R / \mathrm{d} G)$ were of similar magnitude (0.21 to 0.23 ) for the 2 size groups, i.e. Expts II and III.

\section{DISCUSSION}

The findings of this study of a logarithmic relation between food concentration and growth rate (Fig. 2) are in accordance with results on suspension feeding

Table 4. Ciona intestinalis. Carbon budget. AE: assimilation efficiency, GGE: gross growth efficiency, NGE: net growth efficiency, Body: not including tunic, Total: including tunic

\begin{tabular}{|c|c|c|c|c|c|c|c|c|c|c|c|c|}
\hline \multirow{2}{*}{$\begin{array}{l}\text { Food } \\
\text { concentration } \\
\left(\mu g \mathrm{Cl}^{-1}\right)\end{array}$} & \multicolumn{2}{|c|}{ Ingestion $(I)$} & \multicolumn{2}{|c|}{ Growth $(G)$} & \multicolumn{2}{|c|}{ Respiration $(R)$} & \multicolumn{2}{|c|}{$\mathrm{AE}=(G+R) / I$} & \multicolumn{2}{|c|}{$\mathrm{GGE}=G / I$} & \multicolumn{2}{|c|}{$\mathrm{NGE}=G /(G+R$} \\
\hline & $\begin{array}{c}\text { Body } \\
\text { (ug C m }\end{array}$ & $\begin{array}{l}\text { Total } \\
g\left(d^{-1}\right)\end{array}$ & $\begin{array}{l}\text { Body } \\
\text { ( } \mu g \mathrm{C} n\end{array}$ & $\begin{array}{l}\text { Total } \\
\lg \left(\mathrm{d}^{-1}\right)\end{array}$ & $\begin{array}{c}\text { Body } \\
(\mu \mathrm{g} \mathrm{Cm}\end{array}$ & $\begin{array}{l}\text { Total } \\
\left(\mathrm{d}^{-1}\right)\end{array}$ & Body & Total & Body & Total & Body & Total \\
\hline \multicolumn{13}{|l|}{ Expt II } \\
\hline 9 & 20 & 10 & -2 & 9 & 22 & 10 & - & - & - & - & - & - \\
\hline 50 & 136 & 77 & 37 & 20 & 27 & 18 & 0.47 & 0.50 & 0.27 & 0.26 & 0.58 & 0.53 \\
\hline 88 & 175 & 101 & 49 & 28 & 35 & 23 & 0.48 & 0.50 & 0.28 & 0.28 & 0.58 & 0.55 \\
\hline 141 & 194 & 114 & 57 & 37 & 34 & 23 & 0.47 & 0.53 & 0.30 & 0.33 & 0.63 & 0.62 \\
\hline 255 & 230 & 146 & 69 & 48 & 36 & 26 & 0.46 & 0.51 & 0.30 & 0.33 & 0.65 & 0.65 \\
\hline 333 & 294 & 185 & 72 & 49 & 37 & 26 & 0.37 & 0.41 & 0.25 & 0.27 & 0.66 & 0.65 \\
\hline \multicolumn{13}{|l|}{ Expt III } \\
\hline 1 & 8 & 5 & -18 & -11 & 14 & 8 & - & - & - & - & - & - \\
\hline 33 & 90 & 66 & 28 & 26 & 17 & 14 & 0.50 & 0.60 & 0.31 & 0.39 & 0.62 & 0.66 \\
\hline 45 & 142 & 107 & 48 & 44 & 20 & 16 & 0.48 & 0.57 & 0.34 & 0.42 & 0.71 & 0.73 \\
\hline 91 & 206 & 156 & 61 & 56 & - & - & - & - & 0.30 & 0.36 & - & - \\
\hline 178 & 284 & 215 & 76 & 71 & 38 & 29 & 0.40 & 0.47 & 0.27 & 0.33 & 067 & 0.71 \\
\hline 366 & 312 & 243 & 83 & 76 & 33 & 26 & 0.37 & 0.42 & 0.27 & 0.31 & 0.72 & 0.75 \\
\hline
\end{tabular}


Fig. 5. Ciona intestinalis. Mean carbon specific rates of (A) growth $(G)$ and (B) respiration $(R)$ as a function of mean carbon specific rates of ingestion $(I)$ and assimilation $(A)$ of body parts in (a) Expt II and ( Expt III. Fitted lines and equations are shown in the figure. Assimilation rates are calculated as $A=R+G$

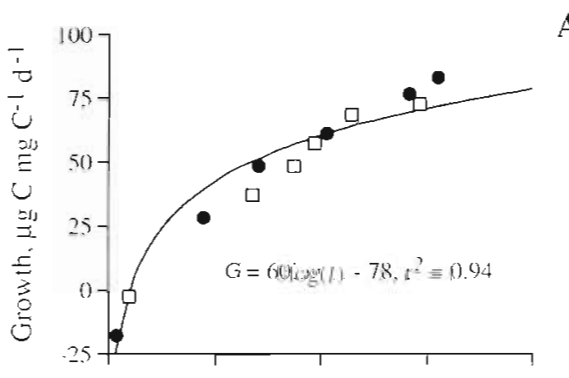

A

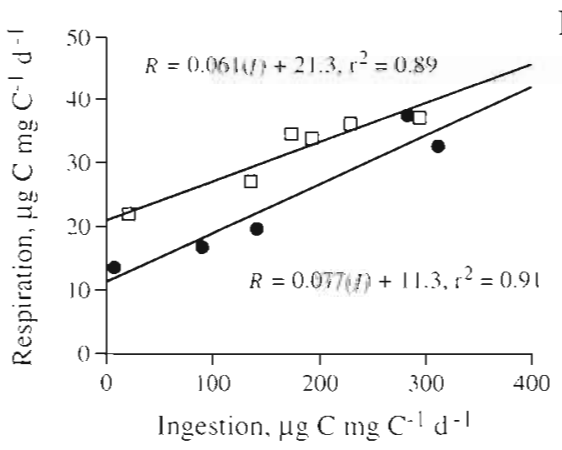

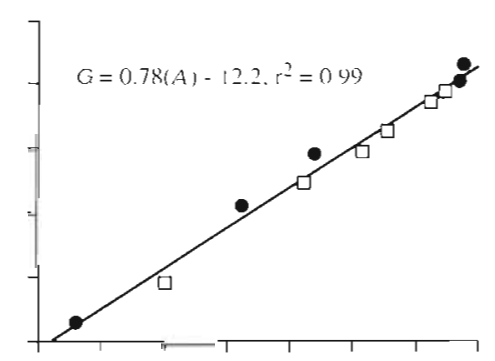

B

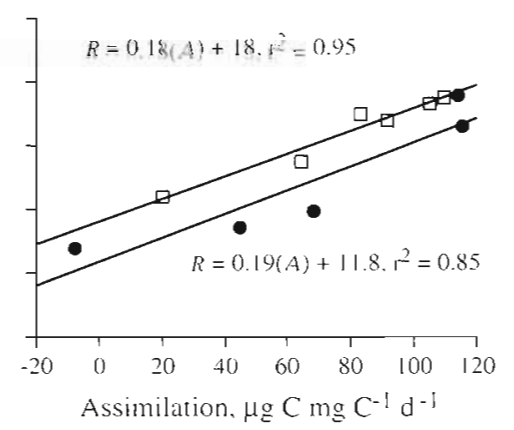

bivalves (Kiørboe et al. 1981, Møhlenberg \& Kiørboe 1981, Riisgård \& Randløv 1981, Jørgensen 1990). Thus, Ciona intestinalis showed increased growth rate with increased algal concentration of up to 4000 to 6000 Rhodomonas cells $\mathrm{ml}^{-1}$, corresponding to approximately 150 to $250 \mu \mathrm{g} \mathrm{Cl}^{-1}$, above which growth rate was not significantly affected by an additional increase in algal cell concentration. It is further seen that growth of body parts is much faster than growth of the tunic, especially in older/larger specimens (Expt II). Specific growth rates in terms of body or total dry weight were found to be greater in specimens collected in late summer (Expt III) than in specimens collected during the winter (Expts I and II). However, upon conversion of growth rates into units of carbon, body growth rates from Expt II approach body growth rates from Expt III. The remaining differences in growth rates at a given food concentration between Expts II and III may be the result of differences in specific ingestion or respiration in ascidians collected in winter and could be related to season.

The different measurements for growth used in this study, i.e. length, total weight and body weight, responded in the same general manner to algal concentration, but were not of similar magnitude and did not show identical responses in all instances, especially not at low algal cell concentrations. The tunic, which accounts for the divergence between the different measurements of size/growth, mainly consists of mucopoly-saccharides secreted from the epidermis (Goodbody 1974). Mesenchyme cells migrate into the tunic, which is permeated with blood vessels in its basal parts, but energy transfer between body and tunic must be considered one-way from the body to the tunic. This was also seen in the growth experiments, where in none of the experiments was there any loss of weight in the tunic at an algal cell concentration of 0 , even when body parts exhibited negative growth. The tunic can thus be considered analogous to the mussel shell, but its gelatinous structure and the fact that $C$. intestinalis easily contracts when disturbed render it difficult to measure in 1 dimension. Changes in body weight may thus be considered the best integrator of growth over time.

Irrespective of age or season, CI varied linearly with growth rate (Fig. 3) and may thus be used as an index of growth in field sampling programs.

In previous studies, ascidian growth rates were calculated in terms of length increment or doubling time (in length or number of zooids in colonial ascidi-

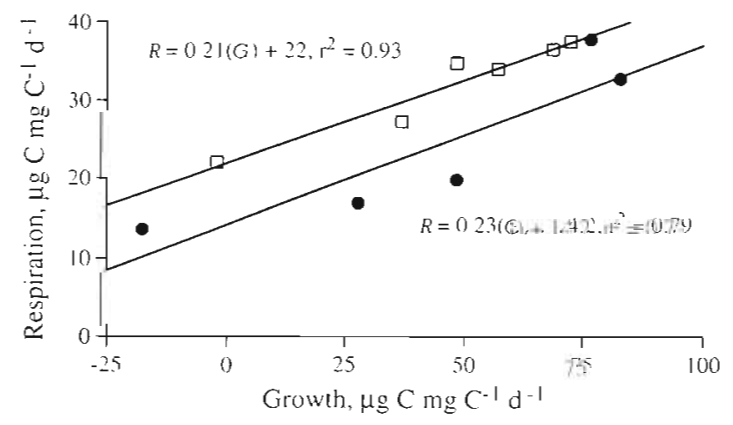

Fig. 6. Ciona intestinalis. Mean carbon specific rate of respiration $(R)$ as a function of mean carbon specific rate of growth $(G)$ of body parts in (a) Expt II and (-) Expt III. Fitted lines and equations are shown on the figure 
Table 5. Growth rates of Ciona intestinalis and other ascidians recorded in nature or in the laboratory. Growth is calculated as specific growth rate from data obtained in the cited literature. Doubling time in the present study is calculated on body (not including tunic) or total (including tunic) weight. C. intestinalis and Styela plicata are solitary ascidians and the others are colonial

\begin{tabular}{|c|c|c|c|c|}
\hline Species & $\begin{array}{c}\text { Temperature } \\
\left({ }^{\circ} \mathrm{C}\right)\end{array}$ & $\begin{array}{c}\text { Growth } \\
\left(\% \text { length } d^{-1}\right)\end{array}$ & $\begin{array}{l}\text { Doubling time } \\
\text { (d) }\end{array}$ & Source \\
\hline \multirow[t]{6}{*}{ Ciona intestinalis } & 10 & & 10 & Yamaguchi (1975) \\
\hline & ca 15 & 2 to 3 & & Yamaguchi (1975) \\
\hline & 15 & 0.7 to $1.1^{d}$ & & Robbins (1985) \\
\hline & $?$ & 2 to 3 & & Dybern (1965) \\
\hline & $?$ & 1.4 & & Millar (1971) \\
\hline & 10 & 2.3 to $2.8^{\mathrm{d}}$ & $9^{\mathrm{a}, \mathrm{b}}, 10.5^{\mathrm{a}, \mathrm{C}}$ & This study \\
\hline Styela plicata & 10 & & 25 & Yamaguchi (1975) \\
\hline Botrylloides violaceus & 10 & & 11 & Yamaguchi (1975) \\
\hline Leptoclinum mitsukurii & 10 & & 8 & Yamaguchi (1975) \\
\hline Botryllus schlosseri & 12 to 17 & & ca 8 & Boyd et al. (1986) \\
\hline
\end{tabular}

ans). Hence, comparison of growth rates obtained in this study with those from the literature is only possible when these measurements are used. Growth, calculated as \% length increase $\mathrm{d}^{-1}$, assuming exponential growth, or doubling time, to the extent that data can be obtained with some precision from figures and tables in the cited literature, is shown in Table 5. It is seen that maximum growth rate from this study was greater or of the same magnitude as growth rates found in the field. When expressing growth of soft bodied organisms as specific (exponential) growth rate, maximum growth rates in Ciona intestinalis of 7 to $8 \% \mathrm{~d}^{-1}$ were higher than found in laboratory studies of other benthic macroinvertebrates like Mytilus edulis (4.4 to $5.6 \% \mathrm{~d}^{-1}$; Kiørboe et al. 1981), Spisula subtruncata (3.1 to $3.6 \% \mathrm{~d}^{-1}$; Møhlenberg \& Kiørboe 1981) or Nereis diversicolor (3.1\% d ${ }^{-1}$; Vedel \& Riisgård 1993). This might be due to either suboptimal conditions in the reported experiments or to $C$. intestinalis being easier to grow in the laboratory. In nature, maximum specific growth rates of 7 to $9 \% \mathrm{~d}^{-1}$ have been found for $M$. edulis (Jørgensen 1990) and $N$. diversicolor (Riisgård pers. comm.) which were of the same magnitude as found in the present study for $C$. intestinalis, indicating that growth potential in benthic suspension-feeding macroinvertebrates is of this size in general.

Suboptimal conditions in growth experiments can be due to high algal concentrations leading to reduced opening of valve gape in mussels and thereby reduced filtration. rates (Riisgård \& Randløv 1981, Riisgård 1991). Filtration rate in Ciona intestinalis was sensitive to increases in algal concentration, decreasing to 30 to $40 \%$ of maximum measured filtration rate $\left(F_{\max }\right)$ at the highest algal concentrations applied (Fig. 2). This is in contrast to Petersen \& Riisgård (1992), who found no effect of algal concentration on $F_{\text {max }}$ at concentrations $<10000$ Rhodomonas sp. cells $\mathrm{ml}^{-1}$ and a $F_{\max }$ lower than found in the present study. However, Petersen \& Riisgard (1992) measured $F_{\max }$ at no less than 2000 cells $\mathrm{ml}^{-1}$, where filtration rate in this study was reduced to 70 to $80 \%$ of $F_{\text {max }}$. Further, the shorter duration of experiments (less than 7 h) in Petersen \& Riisgård (1992) may have concealed long-term effects. Irrespective of filtration rate, growth rates in $C$. intestinalis did not decrease at the highest algal concentrations as suggested for mussels (Riisgård 1991). This is, however, not surprising since growth rate increased with increasing ingestion rate (Fig. 5), and ingestion rate, within the applied range of algal concentrations, increased with increasing algal concentration (Fig. 4). Thus, the rapid response in filtration rate to increases in algal concentration reflects the ability of $C$. intestinalis and other ascidians to regulate food intake rather than suboptimal conditions. Hence, growth is related to amount of ingested or assimilated food rather than filtration rate per se.

Respiration rates in Ciona intestinalis have previously been studied by Shumway (1978), who found an allometric relation between respiration rate and total weight at $10^{\circ} \mathrm{C}$. The maximum respiration rates found in Expts II and III of this study are approximately $80 \%$ of the rates reported by Shumway (1978). However, Shumway (1978) neither shows the feeding level nor blank respiration, and the reported rates may thus be overestimates. The higher specific respiration rates in terms of carbon in larger individuals are in contrast to the allometric relation found by Shumway (1978) and could be due to a difference in measuring technique even though no systematic error was observed. 
The difference could also be related to difference in season between Expts II and III and thus consistent with findings of difference in specific growth (Fig. 4).

The calculated AE for Ciona intestinalis, ranging from 40 to $50 \%$, were in general lower than AE of $40 \%$ at high algal concentrations to $80 \%$ at low algal concentrations found in other filter feeders (Kiørboe et al. 1981, Møhlenberg \& Kiørboe 1981, Riisgård \& Randløv 1981, Navarro \& Winter 1982, Kiørboe et al. 1985). Inclusion of non-algal POM in the calculations of carbon ingestion in this study led to a higher estimate of carbon ingestion and thus lower AE than if only algal carbon had been used. The ascidian net retains particles of 1 to $2 \mu \mathrm{m}$ including larger bacteria with 80 to $100 \%$ efficiency (Jørgensen et al. 1984). Due to the efficient retention of the ascidian net it is obvious that the non-algal POM fraction in calculations of ingestion rate should be included when experiments are carried out in flow-through setups with large volumes of water. With a non-algal POM level of $0.181 \mathrm{mg} \mathrm{DW}^{-1}$ (in water having undergone a Mytilus edulis prefiltration) in addition to algae in the experiments, the nonalgal carbon constituted from $4 \%$ at high algal concentrations to $30 \%$ at the lowest algal concentration of the total carbon ingestion. The difference in growth rates in treatments with no added algae (cf. Expts II and III) illustrates the significance of the non-algal fraction. In Expt III where water at 0 algal cells $\mathrm{ml}^{-1}$ had been microfiltrated before entering the experimental aquarium, there was a significant $(p<0.05)$ loss of weight, while in Expt II with no microfiltration there was no significant loss of weight in non-fed ascidians. Neglecting non-algal carbon leads to AE of between 40 and $80 \%$ in terms of body weight and up to $97 \%$ in terms of total weight, which is comparable with the above-mentioned AE reported for other filter feeders where non-algal POM has not been included in the calculations. Kiørboe et al. (1981) found AE exceeding $100 \%$ in experiments where silt was added to the water but not included in ingestion and concluded that some of the assimilated energy must have been derived from the silt. This probably also applies to experiments with no addition of silt beyond what is present in the aquaria system. Inclusion of non-algal POM in calculations of carbon ingestion will then reduce previously reported values to levels reported here, when compared at equal growth rates, and emphazises that all food sources should be included in compilations of carbon or energy budgets.

Growth efficiencies expressed either in relation to ingestion (GGE) or assimilation (NGE) will strongly depend on the ingestion or assimilation rate (Table 4) and should, for comparison, preferably be expressed as the slope of the linear part of the $G: I$ relation $(\mathrm{d} G / \mathrm{d} I)$ or of the $G$ : $A$ relation (dG/d A) (Kiørboe et al. 1987).
GGE and NGE will aproach $\mathrm{d} G / \mathrm{d} I$ and $\mathrm{d} G / \mathrm{d} A$, respectively, with increasing I or $A$ (Kiørboe et al. 1987). GGE found for Ciona intestinalis approaches a $\mathrm{d} G / \mathrm{d} /$ of 0.23 that can be found from the linear part of the curve in Fig. 5. Similarly, NGE approaches 0.78 with increasing assimilation in both experiments. No size-dependent difference in growth efficiencies could be found as reported for fish (Kiørboe et al. 1987). Jørgensen (1990), however, stated that mussels can maintain constant high growth efficiencies from larval to adult stages.

Specific dynamic action, defined as increment in metabolic rate in association with feeding and generally believed to be the cost of biosynthesis (Kiørboe et al. 1985,1987$)$, was 18 to $19 \%$ of the assimilated energy (Fig. 5). Consistent with this, the cost of growth $(\mathrm{d} R / \mathrm{d} G$ ) was 0.21 to 0.23 (Fig. 6) and in general agreement with the 0.19 that can be calculated for the planktonic copepod Acartia tonsa (Kiørboe et al. 1985). An increase in cost of growth, which has been suggested to follow increase in body mass (Kiørboe et al. 1987), could not be found in Ciona intestinalis, at least in ascidians which have, as those tested, reached the size where they can produce gametes.

In summary, it can be concluded that Ciona intestinalis show a strong dependence of filtration rate on algal cell concentrations and an ability to maintain high growth rates at low food concentrations of 50 to $150 \mu \mathrm{g}$ carbon $\mathrm{l}^{-1}$ corresponding to 1.5 to $4 \mu \mathrm{g}$ chlorophyll $a \mathrm{l}^{-1}$.

Acknowledgements. Thanks to Dr H. U. Riisgård for supervision and kind hospitality at the Fjord Biological Laboratory, to I. Clausen for help in carrying out Expt I, to G. M. Christensen and J. Lonsmann Iversen for supplying Rhodomonas culture, to P. Koefoed for CHN-analysis, to Dr F. Møhlenberg and Prof. C. B. Jørgensen for critically reading the manuscript and to Dr T. Forbes for improving the style of the manuscript. This study was partly supported by the National Board of Environmental Protection (HAV 90) and the Danish Research Academy.

\section{LITERATURE CITED}

Boyd, H. C., Brown, S. K., Harp, J. A., Weissmann, I. L. (1986). Growth and sexual maturation of laboratory-cultured Monterey Botryllus schlosseri. Biol. Bull. 170: 91-109

Dybern, B. I. (1963). Biotope choice in Ciona intestinalis (L.) Influence of light. Zool. Bidr. Upps. 35: 589-602

Dybern, B. I. (1965). The life cycle of Ciona intestinalis (L.) f. typica in relation to the environmental temperature. Oikos 16: 109-131

Goodbody, 1. (1974). The physiology of ascidians. Adv. mar. Biol. 12: 2-149

Gulliksen, B. (1972). Spawning, larval settlement, growth, biomass, and distribution of Ciona intestinalis L. (Tunicata) in Borgenfjorden, North-Tröndelag, Norway. Sarsia 51: 83-96

Jespersen, A.-M, Christoffersen, K. (1987). Measurements of 
chlorophyll a from phytoplankton using ethanol as extraction solvent. Arch. Microbiol. 109: 445-454

Jorgensen, C. B. (1990). Bivalve filter feeding: hydrodynamics, bioenergetics, physiology and ecology. Olsen \& Olsen, Fredensborg

Jørgensen, C. B., Kiørboe, T., Møhlenberg, F., Riisgård, H. U. (1984). Ciliary and mucus-net filter feeding, with special reference to fluid mechanical characteristics. Mar. Ecol. Prog. Ser. 15: 283-292

Kiørboe, T., Møhleaberg, F., Hamburger, K. (1985). Bioenergetics of the planktonic copepod Acartia tonsa: relation between feeding, egg production and respiration, and composition of specific dynamic action. Mar. Ecol. Prog. Ser. 26: 85-97

Kiørboe, T. Møhlenberg, F, Nøhr, O. (1981). Effect of suspended bottom material on growth and energetics in Mytilus edulis. Mar. Biol. 61: 283-288

Kiorboe, T., Munk, P., Richardson, K. (1987). Respiration and growth of larval herring Clupea harengus: relation between specific dynamic action and growth efficiency. Mar. Ecol. Prog. Ser. 40: 1-10

Millar, R. H. (1952). The annual growth and reproductive cycle in four ascidians. J. mar. biol. Ass. U.K. 31: 41-61

Millar, R. H. (1971). The biology of ascidians. Adv. mar. Biol. 9: $1-100$

Møhlenberg, F., Kiørboe, T. (1981). Growth and energetics in Spisula subtruncata (Da Costa) and the effect of suspended bottom material. Ophelia 20:79-90

Navarro, J. M., Winter, J. E. (1982). Ingestion rate, assimila-

This article was submitted to the editor tion efficiency and energy balance in Mytilus chilensis in relation to body size and different algal concentrations. Mar. Biol. 67: 255-266

Petersen, J. K., Riisgård, H. U. (1992). Filtration capacity of the ascidian Ciona intestinalis and its grazing impact in a shallow fjord. Mar. Ecol. Prog. Ser, 88: 9-17

Riisgård, H. U. (1991). Filtration rate and growth in the blue mussel., Mytilus edulis Linneaus: dependence on algal concentration. J. Shellfish. Res. 10: 29-35

Riisgård, H. U., Randløv, A. (1981). Energy budgets, growth and filtration rates in Mytilus edulis at different algal concentrations. Mar. Biol. 61: 227-234

Robbins, I. J. (1985). Ascidian growth and survival at high inorganic particulate concentrations. Mar. Pollut. Bull. 16: $365-367$

Shumway, S. E. (1978). Respiration, pumping activity and heart rate in Ciona intestinalis exposed to fluctuating salinities. Mar. Biol. 48: 235-242

Steffensen, J. F. (1989). Some errors in respirometry of aquatic breathers: how to avoid and correct for them. Fish Physiol. Biochem. 6: 49-59

Vedel, A., Riisgård, H. U. (1993). Filter-feeding in the polychaete Nereis diversicolor. growth and bioenergetics Mar. Ecol. Prog. Ser. 100: 145-152

Yamaguchi, M. (1975). Growth and reproductive cycles of the marine fouling ascidians Ciona intestinalis, Styela plicata, Botrylloides violaceus, and leptoclinum mitsukurii at Aburatsubo-Moroiso inlet (Central Japan). Mar. Biol. 29: $253-259$

Manuscript first received: April 11, 1994

Revised version accepted: December 6, 1994 